\title{
Holocene history of Taxus baccata in the Basque Mountains (Northern Iberian Peninsula)
}

\author{
Sebastián Pérez-Díaz(*****), José Antonio López-Sáez(**), \\ Mónica Ruiz-Alonso(**), Lydia Zapata(***) \& Daniel Abel-Schaad(**)
}

\begin{abstract}
Pérez-Díaz, S., López-Sáez, J.A., Ruiz-Alonso, M., Zapata, L., \& Abel-Schaad, D. Holocene history of Taxus baccata in the Basque Mountains (Northern Iberian Peninsula). Lazaroa 34: 29-41 (2013).

Palaeobotanical studies are a very interesting tool for evaluating past vegetation, climatic variability and human pressure on the landscape. In this paper we offer an overview of Holocene evolution of the yew (Taxus baccata L.) in the Basque Mountains (Northern Iberian Peninsula). For this purpose, we have collected all macro- and micro-remain evidence of the presence of yew within its chronological framework. The results suggest the existence of a period of expansion of yew populations during the Middle Holocene and a regression phase in the Late Holocene.
\end{abstract}

Keywords: Palaeobotanical record, Taxus baccata L., Human impact, Basque Mountains, Northern Iberian Peninsula, Holocene.

Resumen: Pérez-Díaz, S., López-Sáez, J.A., Ruiz-Alonso, M., Zapata, L., \& Abel-Schaad, D. Historia holocena de Taxus baccata en las Montañas Vascas (Norte de la Peninsula Ibérica). Lazaroa 34: 29-41 (2013).

Los estudios paleobotánicos son una herramienta de gran interés para conocer la evolución de la cubierta vegetal del pasado, además de las condiciones climáticas y la dinámica antrópica. Pero también resulta muy útil a la hora de evaluar la historia de particular de algunas especies. En este trabajo ofrecemos una visión sintética de la evolución holocena del tejo (Taxus baccata L.) en las montañas vascas (Norte de la Península Ibérica). Para ello hemos recogido todos los depósitos con macrorestos o microrrestos botánicos de tejo, así como su adscripción cronológica. Los resultados sugieren la existencia de un período de expansión de los tejos durante el Holoceno medio, así como una fase de regresión durante el Holoceno final.

Palabras clave: Registro paleobotánico, Taxus baccata L., Montañas Vascas, Norte de la Península Ibérica, Holoceno.

\section{INTRODUCTION}

Global palaeoenvironmental reconstructions with Holocene chronologies have increased markedly in recent years, focusing on the evolution of the vegetal landscape, climatic variability and increasing human influence on ecosystems. However, only a few studies pay attention to the particular evolution of certain species, and attempt to explain possible expansions or declines, or to understand their role in the current landscape con- figuration. In this paper we evaluate the evolution of yew (Taxus baccata) in the Basque Mountains (Northern Iberian Peninsula) during the Holocene.

The Basque Mountains do not form a large territory, but it is quite mountainous, with a significant variety of climates and orographic conditions, covering the eastern part of the current Province of Cantabria, the Basque Country, the north of Navarre and Treviño (Figure 1). It is located between the Aquitaine basin (France), the

* GEODE, UMR 5602 CNRS, Université Toulouse-Le Mirail. 5, Allées A. Machado-31058 Toulouse Cedex 9 (France). Email: sebas.perezdiaz@gmail.com.

** Archaeobiology Group, Institute of History, Spanish National Research Council (CCHS-CSIC), Albasanz 26-28, 28037 Madrid, Spain.Email: joseantonio.lopez@cchs.csic.es,monica.ruiz@cchs.csic.es, dabel222@hotmail.com.

*** University of the Basque Country (UPV/EHU). Francisco Tomás y Valiente, s/n. Apdo. 2111. 01006 Vitoria-Gasteiz, Spain. Email: 1ydia.zapata@ehu.es. 


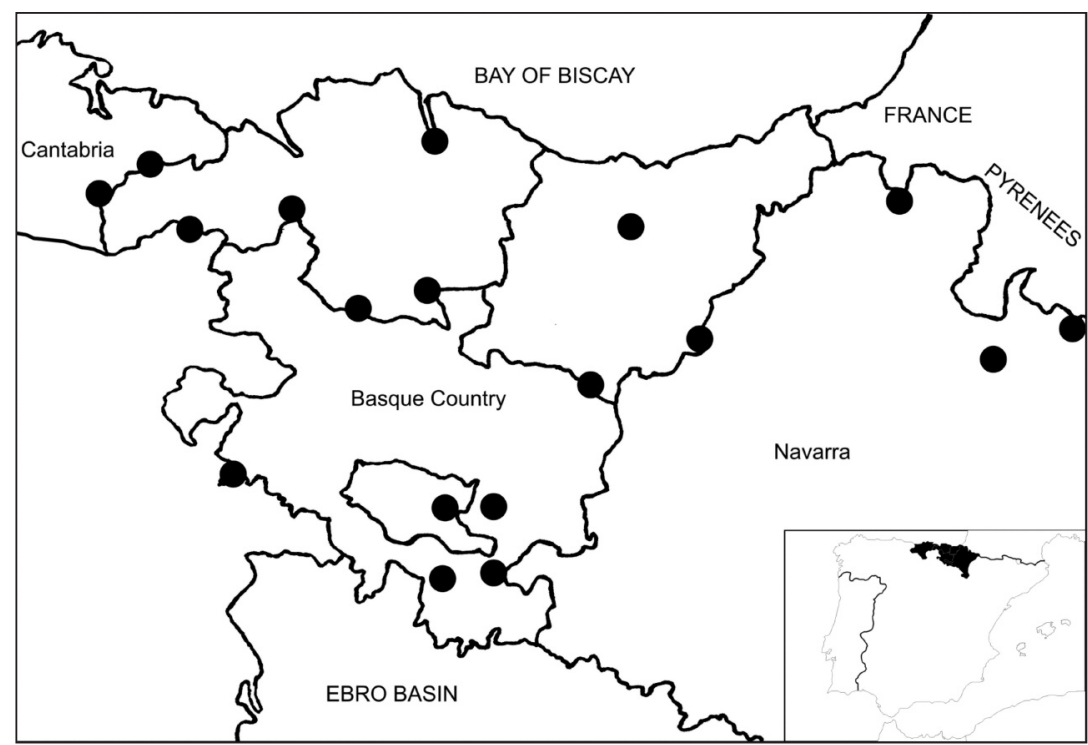

Figure 1. - Study area and present day distribution of Taxus baccata populations (ANTHOS, 2013).

Bay of Biscay (in the north), the Ebro basin (in the south), the Pyrenees (in the east) and the Asturian Massif (in the west). The existence of mountain barriers in parallel to the coastline limits the progressive arrival of Atlantic influences, favouring a complex and rich floristic variability (GONZÁLEZ \& al., 1998). From a phytogeographic point of view, this area lies within the two biogeographical regions in the Iberian Peninsula: Eurosiberian and Mediterranean (AsEguINOLZA \& al., 1996).

Taxus woods are extremely rare and unique formations all over Europe, with a clear regression dynamic in many parts of the Mediterranean region (MERCURI \& al., 2012). Their conservation is among the priorities of the European Union and they are designated as "Priority Woodland Types" in the Habitats Directive list (EEC Directive 92/43). In the Iberian Peninsula, yew is included in catalogues of endangered species in many regions, including Cantabria, the Basque Country and Navarre (SIERRA, 2010).

Yew (Taxus baccata) is a relic tree species belonging to the family Taxaceae. The first fossil records appear in the Triassic (Paleotaxus), while the genus Taxus is documented as early as the Jurassic, with close proximity to the existing species of Taxus baccata (ABELLA, 2009). It must have become most widespread in the successive Tertiary and the Quaternary interglacial periods, favoured by the installation of temperate and humid conditions (DEFORCE \& BASTIAENS, 2003).

It is an important part of the current vegetal heritage, because it is an appreciated raw material and possesses a symbolic value for many rural communities (ABELLA, 2009). Yew wood is of very good quality because it is hard, compact, tough and elastic, easy to work, can be bent by vapour, turned and polished. It has several traditional uses, from the manufacturing of bows, beams and wagons to household utensils, like furniture and doors, and also as fuel. In addition, even today, yew is considered a sacred tree in many places, the witness to millennial important social events because of its protective and spiritual value (CORTÉs \& al., 2000).

In prehistoric times the use of yew wood for manufacturing hunting weapons has been documented from the earliest periods of the Palaeolithic. One of the finds was the Lower Palaeolithic spear at Clacton-on-Sea (Essex, United Kingdom), discovered in 1911 and dated to the Holsteinian Interglacial (Middle Pleistocene) (OAKLEY \& al., 1977). Another interesting find is the spear, excavated in 1948 at the site of Lehringen (Lower Saxony, Germany), and dated in the Eemian In- 
terglacial (THIEME \& VEIL, 1985). In more recent chronologies some other implements have been documented, such as bows. The oldest is dated ca. 8000 cal BP in Stellmoor (Hamburg, Germany) (RAUSING, 1967), but there are others like the Meare Heath bow, discovered in 1961 in a peat bog in Somerset (United Kingdom) (CLARK \& Godwin 1962), and the one found with the "Iceman" in 1991 in a melting glacier in the Tyrolean Alps on the Italian-Austrian border, dated $c a$. 5300 cal BP (SPINDLER, 1994). In the Iberian Peninsula, the prehistoric use of yew has been documented, for example, in the archaeological site of La Draga (Banyoles, Girona), where several artefacts made of yew have been found, such as bows and other domestic tools (PALOMO \& al., 2005; Bosch \& al., 2006; Bosch \& al., 2011).

The yew is a tree which, from immemorial times, has attracted both admiration and the distrust of humans. However, little is known about the ancient history of this tree, its origin, expansion and decline in many regions of Europe (COSTA Tenorio \& al., 2005). The aim of this paper is to offer a review of the history of yew formations in the Basque Mountains during the Holocene, evaluating its development and decline in the light of the available palaeobotanical data.

\section{PRESENT DAY ECOLOGY AND DISTRIBUTION}

The genus Taxus includes 12 species, only one native to Europe, with few morphological features to distinguish some species from others (COPE, 1998; PARMAR \& al., 1999). Therefore, several authors have suggested the presence of a single collective Taxus baccata species, with local variations (Thomas \& Polwart, 2003; SierRa, 2010).

It grows best in oceanic climates with relatively mild winters, abundant rainfall and high humidity. It is located in almost any soil type, growing best on deep, moist and sandy loams and well-drained clays, and worse on dry soils. The largest and purest present-day populations are in the British Isles, Poland, Romania and the Caucasus Mountains. Outside these optimum areas, yew extends northwards to $63^{\circ}$ in Norway and
Sweden (eventually limited by low temperatures), eastwards to Estonia (limited by the continental climate) and southwards to several Mediterranean countries, such as Greece, Italy, Spain, Portugal and North Africa (limited here by drought, high temperatures and low humidity) (THOMAs, 2010).

In the Iberian Peninsula, yew woods are plant communities of great scarcity and singularity. Their current distribution includes several regions; although they are most common in the north, they also appear on mountain ranges in the south. In general, yew trees are usually found isolated or as a part of small groups within other forests, rarely as monospecific formations (COSTA TENORIO \& al., 2005). In the Basque Mountains, yews currently grow in several environments, from oceanic-influenced areas near the coastline to inland mountain areas at higher altitudes, with a more seasonal climate (Figure 1). They are normally confined to areas of low economic use, in rugged and inaccessible places, but always in moist soils with absence of prolonged droughts in summer. They grow on different kinds of substrate, including materials such as granite, shale, slate, sandstone, marl or limestone. They are found dispersed throughout the Province of Cantabria, especially in the western part, in the main mountain ranges in the Basque Country and in northern Navarre (Aseguinolaza \& al., 1996; Costa TenORIO \& al., 2005; SCHWEDTNER \& al., 2007; VARAS-СOBO, 2007).

Despite its wide current distribution, yew never becomes common in this region. It usually appears in isolation (sometimes with a few specimens), associated with other plant communities such as deciduous forests. It is quite frequent to find yew trees in the domain of beech, particularly in the vicinity of some eutrophic beech forests, located on limestone slopes with rock outcrops, always in marginal positions. It is also located in mixed forests on limestone slopes, a type of thin forest with low sized specimens, conditioned by poor soils (Gil García \& al., 1995; AsEguinOlaZA \& al., 1996; GARCíA, 2007). In the Basque Mountains only two well preserved yew forests are known, in Sierra de Aralar, with over 1000 trees, and at Quinto Real, in the north of Navarre (SCHWEDTNER \& CÁRCAMO, 2001; SCHWEDTNER \& al., 2007). 


\section{THE PALAEOBOTANICAL DATASET}

The Taxus palaeobotanical record for the Holocene in the Basque Mountains is not very rich. All palaeobotanical studies with any type of Taxus remain have been considered. In total, the dataset consists of 25 sites (Table 1). Results include pollen and charcoal remains from both archaeological and non-anthropic deposits (peat bogs and marshes) from the north-eastern Cantabrian region (Figure 2). Palaeobotanical research carried out in non-anthropic sequences is one of the best palaeoenvironmental tools to acquire data about the composition and evolution of the vegetal landscape, climatic conditions and anthropic activities, frequently related to wide chronological frameworks. In this region, only eight studies are available. However, in this work, more abundant palaeobotanical studies from archaeological sites have also been considered. Despite covering shorter chronological periods (only during the human occupation of the site), they can provide interesting data about the vegetal landscape and its human management.

All radiocarbon dates included in this paper have been calibrated using Calib Radiocarbon Calibration program (6.0; REIMER \& al., 2004) and are given as cal BP $(2 \sigma, 95.4 \%)$. In the sites without radiocarbon dates, the adopted chronology is that given by the author.

\section{HOLOCENE PALAEOBOTANICAL RECORDS OF TAXUS IN THE BASQUE MOUNTAINS}

The palaeobotanical record only documents two types of Taxus remains, pollen and charcoal, no seeds or other plant macro-remains have been found. Taxus pollen is inaperturate, between 20-

Table 1

Holocene palaeobotanical sequences with any Taxus remain in the Basque Mountains (UTM Zone 30)

\begin{tabular}{|c|c|c|c|c|c|}
\hline $\mathrm{N}^{\mathrm{o}}$ & SITE & LOCATION & NATURE OF SITH & TYPE OF REST & REFERENCE \\
\hline 1 & Los Tornos & Soba & Peat bog & Pollen & Peñalba, 1989 \\
\hline 2 & El Mirón & Ramales de la Victoria & Archaeological & Charcoal & Zapata, 2012 \\
\hline 3 & Zalama & Ordunte & Peat bog & Pollen & Pérez-Diaz et al, unpublished \\
\hline 4 & Arenaza I & Galdames & Archaeological & Pollen & Isturiz \& Sánchez-Goñi, 1990 \\
\hline 5 & Argarbi Ib & Aralar & Archaeological & Charcoal & Mujika et al, in press \\
\hline 6 & Arrubi & Enirio-Aralar & Archaeological & Charcoal & Ruiz-Alonso, 2003/2007 \\
\hline 7 & Buruntza & Andoain & Archaeological & Charcoal & Olaetxea, 1997 \\
\hline 8 & Inurritza & Zarauz & Marsh & Pollen & Peñalba, 1989 \\
\hline 9 & Mulisko Gaina & Urnieta-Hernani & Archaeological & Pollen & Peñalba, 1987 \\
\hline 10 & Ondarre & Aralar & Archaeological & Charcoal & Mujika et al, in press \\
\hline 11 & Playaundi & Irún & Marsh & Pollen & Sánchez-Goñi, 1996 \\
\hline 12 & Urtiaga & Deba & Archaeological & Pollen & Sánchez-Goñi, 1993a, 1993b \\
\hline 13 & Aizpea & Aribe & Archaeological & Charcoal & Zapata 2001 \\
\hline 14 & Atxuri & Maya de Baztán & Peat bog & Pollen & Peñalba, 1989 \\
\hline 15 & Belate & Narbarte & Peat bog & Pollen & Peñalba, 1989 \\
\hline 16 & Fuente del Vaquero & Natural Park of Izki & Peat bog & Pollen & Pérez-Díaz, 2012 \\
\hline 17 & Atxoste & Vírgala & Archaeological & Charcoal & Ruiz-Alonso, unpublished \\
\hline 18 & Kanpanoste & Vírgala & Archaeological & Pollen & Sánchez-Goñi, 2004 \\
\hline 19 & Mendandia & Sáseta (B) & Archaeological & Pollen & Iriarte, 2006 \\
\hline 20 & Saldropo & Ceanuri & Peat bog & Pollen & Peñalba, 1989 \\
\hline 21 & Los Husos I & Elvillar & Archaeological & Charcoal & Ruiz-Alonso, unpublished \\
\hline 22 & Los Husos II & Elvillar & Archaeological & Charcoal & Ruiz-Alonso, unpublished \\
\hline 23 & Peña Larga & Cripán & Archaeological & Charcoal & Ruiz-Alonso, unpublished \\
\hline 24 & Peña Parda & Laguardia & Archaeological & Charcoal & Ruiz-Alonso \& Zapata, 2003 \\
\hline 25 & San Cristóbal & Laguardia & Archaeological & Pollen, Charcoal & $\begin{array}{c}\text { Pérez-Díaz, 2012, } \\
\text { Ruiz-Alonso, unpublished }\end{array}$ \\
\hline
\end{tabular}




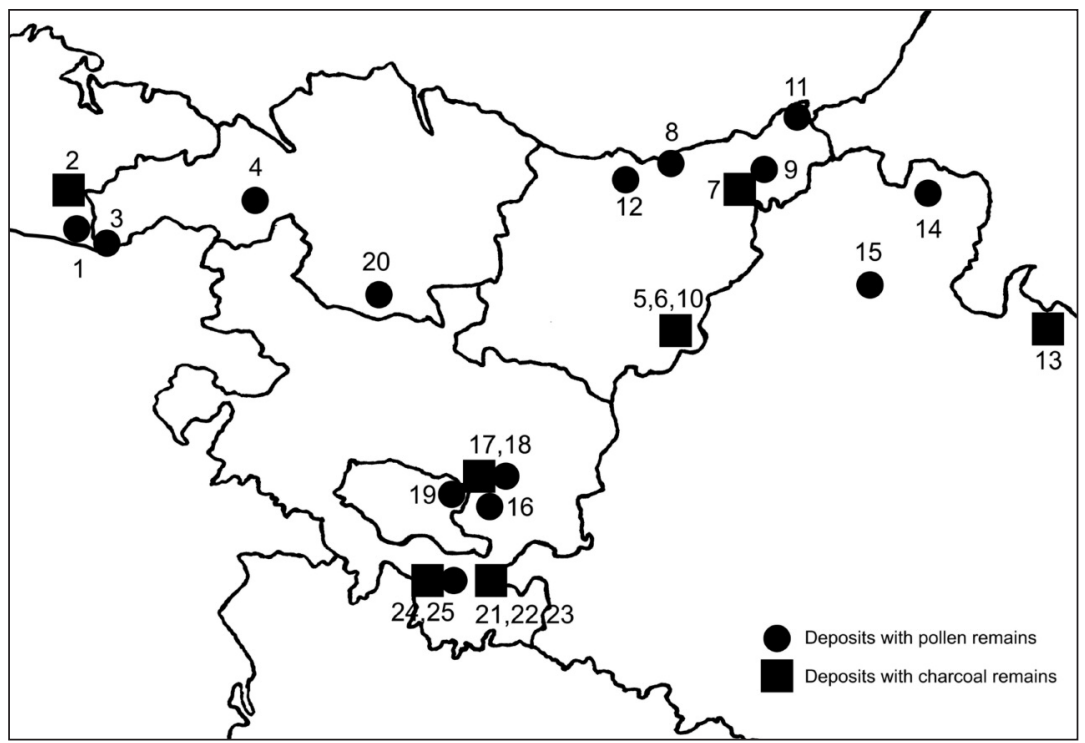

Figure 2. - Location of Holocene deposits with Taxus pollen and charcoal remains in the Basque Mountains.

$25 \mu \mathrm{m}$. The exine is intectated with a scabrate or microgemate sculpturing (MOORE \& al., 1991; BEUG, 2004), and is very sensitive to corrosion (HAVINGA, 1964, 1967), so it is not a very common taxon in pollen records. For the same reason, its absence in the record does not necessarily imply its absence in the surrounding environment. Taxus wood and charcoal are easy to differentiate from other tree species in general and from other gymnosperms in particular. The transverse section presents a gradual transition between early and latewood, as well as thick-walled cells. Resin canals are absent. The tangential section displays uniseriate tracheid pits, homocellular rays and spiral thickenings (SCHWEINGRUBER, 1990).

\section{EASTERN CANTABRIAN RANGE}

The earliest Taxus remains in the Eastern Cantabrian Range are the pollen grains identified in Los Tornos (PeÑAlba, 1989) and Zalama (PÉREZDíAz \& al., unpublished data) peat bogs (Figure 2), where, between $c a .6000-3000 \mathrm{cal} \mathrm{BP}$, the pollen diagrams show a continuous presence of Taxus with low values $(<1 \%)$. In the nearby cave of El Mirón, the archaeological Levels 8 (4680 \pm $60 \mathrm{BP}, 5580-5310 \mathrm{cal} \mathrm{BP}), 7(3740 \pm 120 \mathrm{BP}$,
4430-3730 cal BP) and 6 show the presence of high values of Taxus charcoal (maxima of 40\%) in the retrieved macro remains. In Levels 4, 3 (3700 $\pm 40 \mathrm{BP}, 4150-3920 \mathrm{cal} \mathrm{BP})$ and 2, Taxus values are lower (ZAPATA, 2012).

\section{COAST AND INLAND VALLEYS}

The presence of Taxus palaeobotanical remains in the coast and inland valleys is very poor ( $\mathrm{Fi}$ gure 2). The oldest evidence is the scattered presence of its pollen in the Early Holocene record of two archaeological caves, Urtiaga (SÁNCHEZGoÑI, 1993) and Arenaza I (IstuRIZ \& SÁNCHEZGoÑI, 1990), in Azilian levels, dated before 9600 $\pm 180 \mathrm{BP}(11390-10300 \mathrm{cal} \mathrm{BP})$ in the case of Arenaza (Late Glacial or Early Holocene). Other finds are scattered charcoal occurrences in Ondarre (MuJika \& al., in press) at $5050 \pm 50 \mathrm{BP}$ (5910-5620 cal BP), in the hillfort of Buruntza (OlaetXeA, 1997) during the Iron Age (3000 \pm $60 \mathrm{BP}, 3350-3000 \mathrm{cal} \mathrm{BP}, 2810 \pm 90 \mathrm{BP}, 3200-$ $2750 \mathrm{cal} \mathrm{BP}, 2475 \pm 75 \mathrm{BP}, 2730-2360 \mathrm{cal} \mathrm{BP}$, $2270 \pm 80 \mathrm{BP}, 2650-2040 \mathrm{cal} \mathrm{BP}$ and $2180 \pm 80$ BP, 2340-1990 cal BP), in Argarbi Ib (MUJIKA \& al., in press) during the Roman Period (1760 \pm 70 BP, 1860-1530 cal BP), and in Arrubi (RuIZAlOnso, 2003/2007) (1440 \pm 100 BP 1280-800 
cal BP, $1110 \pm 50 \mathrm{BP}, 1170-930 \mathrm{cal} \mathrm{BP})$. Its pollen is also present in the marsh of Playaundi (SÁNCHEZ-GoÑI, 1996) after $2740 \pm 90$ BP (3140-2620 cal BP), in the marsh of Inurritza in historical periods (PEÑAlBA, 1989), and, finally, in the archaeological site of Mulixko Gaina ca. $2630 \pm 90$ BP (2950-2370 cal BP) (PEÑAlBA, 1987).

\section{PRE-PYRENNES}

Three of the most interesting deposits containing Taxus palaeobotanical remains are located in the Pre-Pyrenees in Navarre (Figure 2). The oldest is the archaeological site of Aizpea (ZAPATA, 2001), where the scarce presence of Taxus charcoal is documented from $c a .7160 \pm 70 \mathrm{BP}(8160$ $7850 \mathrm{cal}$ BP). Between $6830 \pm 70 \mathrm{BP}(7830-7570$ $\mathrm{cal} \mathrm{BP})$ and $6370 \pm 70 \mathrm{BP}(7420-7170 \mathrm{cal} \mathrm{BP})$ its continuous presence is detected, with low values that increase strongly in the upper part of the sequence (anthracological zone 3), with no radiocarbon dates. In the peat bog of Atxuri, Taxus pollen appears between $\mathrm{ca}$. 6500-5000 cal BP with low values (1-2\%). After that, the diagram shows scattered occurrences in the $3^{\text {rd }}$ and $2^{\text {nd }}$ millennia cal BP (PEÑALBA, 1989). Finally, in the peat bog of Belate, between ca. 5700-2300 cal $\mathrm{BP}$, the diagram shows the continuous presence of Taxus pollen (PeÑAlBA, 1989), with remarkably high values reached between $c a$. 5500-4750 cal BP (maximum of $6 \%$ ).

\section{Sub-ATLANTIC AND SUB-MEDITERRANEAN REGION}

The oldest presence of Taxus palaeobotanical remains during the Holocene in the central sector of the Basque Country and Navarre come from several archaeological sites (Figure 2). In Atxoste (RuIZ-Alonso, unpublished), scattered charcoal remains have been identified dated to $8030 \pm 50$ BP, 9030-8660 cal BP and $7810 \pm 40$ BP, 8700$8460 \mathrm{cal} \mathrm{BP}$, and $7340 \pm 50 \mathrm{BP}, 8310-8020$ ) (AlDAY, 2002). In Kanpanoste (SÁNCHEZ-GoÑI, 2004) the diagram shows scattered pollen occurrences dated to $7620 \pm 70 \mathrm{BP}(8580-8320 \mathrm{cal}$ $\mathrm{BP})$ and in Mendandia between $7810 \pm 50 \mathrm{BP}$, $8750-8450 \mathrm{cal} \mathrm{BP}$ and $7780 \pm 60 \mathrm{BP}, 8710-8420$ cal BP (IRIARTE, 2006). Pollen has also been detected in peat bogs, such as Saldropo between $c a$. 5500-2700 (PeÑalba, 1989) and Fuente del Vaquero in the Medieval Period (PÉREZ-DíAZ, 2012; PÉreZ-Díaz \& LóPEZ-SÁeZ, in press).

\section{Sierra de Cantabria (Ebro Valley)}

This region, in the southernmost part of the Basque Country, provides a few interesting archaeological sequences for the understanding of Taxus dynamics during the Holocene (Figure 2). In the Peña Larga site (Ruiz-Alonso, unpublished) a continuous charcoal presence is detected between 7600-4500 cal BP, with high values. After that, percentages are lower than $10 \%$. Very similar is the case of Los Husos I (RuIZ-Alonso, unpublished) with high values (>10\%) between ca. 7300-4300 cal BP and lower until $3000 \mathrm{cal}$ $\mathrm{BP}$, when it disappears from the sequence. In the nearby site of Los Husos II (RUIZ-Alonso, unpublished) the continuous charcoal presence is dated between $c a$. 6400-5300 cal BP. Taxus macro remains were also found at the Peña Parda site, but in this case no radiocarbon dates are available (Ruiz-Alonso \& ZAPATA, 2003). Finally, in San Cristóbal, the finds of charcoal are dated from 5900 until 4300 cal BP. This is the only site where both charcoal and pollen remains have been documented (PÉREZ-DíAZ, 2012; PÉREZ-DíAZ \& al., 2010).

\section{DISCUSSION. THE HOLOCENE HISTORY OF TAXUS BACCATA}

\section{THE Holocene EXPANSION OF TAXUS}

As mentioned above, the genus Taxus is documented at least from the Jurassic, although it seems that it reached its full extension during the Tertiary and the Quaternary (DEFORCE \& BASTIAENS, 2003). In the Basque Mountains the earliest evidence of Taxus fossil remains comes from the Pleistocene sequence at the archaeological site of Lezetxiki (SÁNCHEZ-GoÑI, 1993), unfortunately with no absolute dates. In more recent chronologies it is also identified in the archaeo- 
logical sites of Atxoste (15120-13350 cal BP, ALDAY \& al., 2012) and Kukuma (IsturIZ, 1997), in the Late Pleistocene. But it is in the Holocene when the palaeobotanical record documents more abundant fossil remains of yew.

The Early Holocene record ( $c a .11,500-8600$ cal BP) also indicates its presence in this territory, as can be observed in certain archaeological deposits such as the caves of Urtiaga and Arenaza, although in both cases the diagrams show scattered pollen occurrences (Figure 3). It has also been recorded in such archaeological deposits as Atxoste, Mendandia and Kanpanoste, ca. 9000$8000 \mathrm{cal}$ BP. In the first case, only a few pieces of charcoal have been identified, while in Mendandia and Kanpanoste, the finds are isolated pollen occurrences. It also happens that these three deposits are quite close to each other, in the SubMediterranean valleys, so the presence of yew in this region during the Early Holocene can be safely assumed.

However, it is during the Middle Holocene ( $c a$. $8600-4600$ cal BP) when a significant increase in fossil finds of yew is detected, particularly from ca. $8000 \mathrm{cal}$ BP onwards. They mostly correspond to fragments of wood charcoal from archaeological sites located in the Pre-Pyrenees in
Navarre and in the Sierra de Cantabria (Figure 3). In the case of Aizpea, yew appears as part of a deciduous forest from $\mathrm{ca} .8000 \mathrm{cal}$ BP. However, it is particularly after the archaeological level dated to $6370 \pm 70 \mathrm{BP}(7420-7170 \mathrm{cal} \mathrm{BP})$ when yew reaches its highest values. This coincides with the maximum extension of the local deciduous forest of hazel, oak, birch, alder and lime, according to the palynological record (IRIARTE, 2001), and with the first farmers (Early Neolithic). In the southern areas of the Basque Country, in the archaeological deposits in the Sierra de Cantabria, yew is also first documented in the charcoal record $c a .7600$ cal BP, again within deciduous forest with oak, hazel, birch and alder, as in the case of Peña Larga (IRIARTE, 1997; PÉREZ-DíAZ, 2012). In another archaeological site, this time in the eastern Cantabrian Mountains, the charcoal record from El Mirón Cave shows a major use of yew as fuel ca. 5500 cal BP (ZAPATA, 2012).

Therefore, the oldest data documenting a relatively large presence of yew in the Holocene come from charcoal records in archaeological contexts. But this poses the question: is the widespread use of yew due to its abundance in local forests, or does it respond to specialization in the provision of fuel? When interpreting these records we must

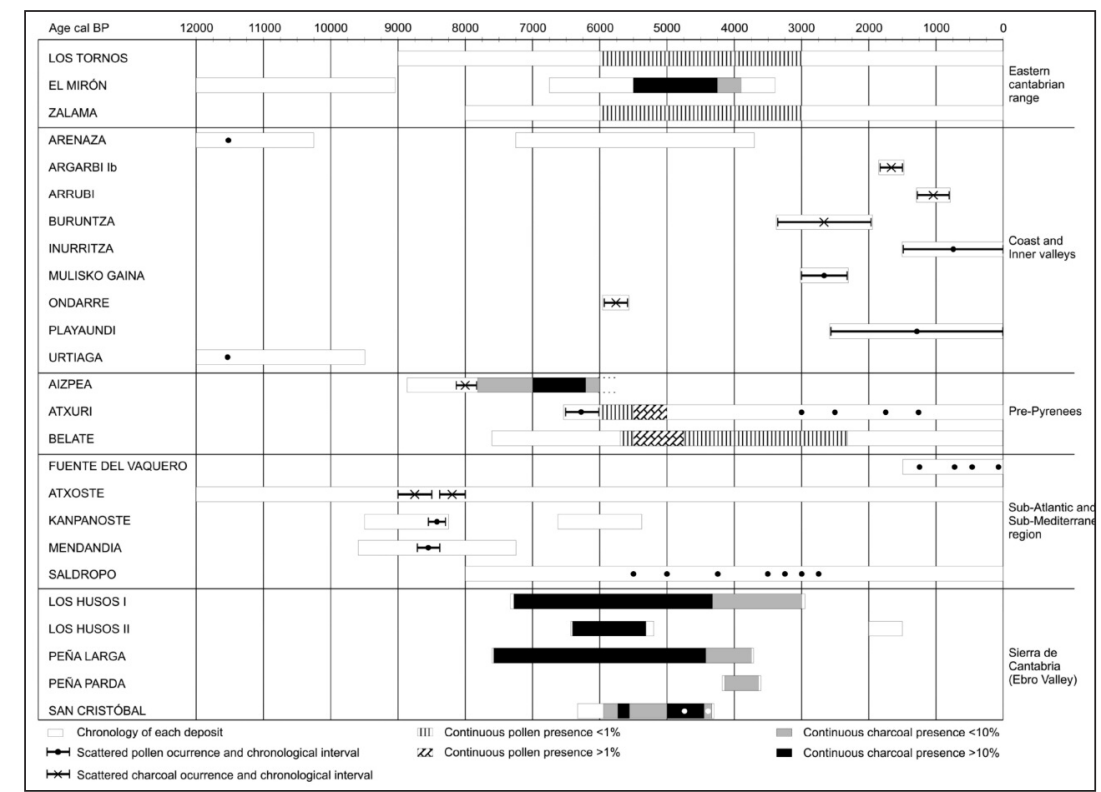

Figure 3. - Pollen and charcoal occurrences of Taxus in Holocene sequences from the Basque Mountains. 
take into account two main approaches, palaeoethnobotany and palaeoecology. The former emphasizes the importance of human selection of fuel, based on criteria such as its proximity, suitability for different functionalities and toughness (SMART \& HOFFMAN, 1988; THOMPSON, 1994). The second approach, palaeoecology, stresses that the main criterion when collecting wood is the proximity to the site, turning the charcoal record into a direct function of the surrounding vegetation cover, like palynology, provided that certain conditions are fulfilled (VERNET, 1991; CHABAL, 1997; THÉRYPARISOT \& al., 2010).

In our opinion, from the charcoal record alone it is difficult to determine the real significance of the presence of yew in the landscape, because anthracological evidence linked to human settlements can be used as an indicator of presence rather than a quantitative estimate of the importance of yew in the landscape. The best way to solve this issue would be to compare other palaeoenvironmental records, but, in this case, they are absent. However, the charcoal record, with significant values of yew documented in PrePyrenean Navarre and in the southern sector of the Basque Country, definitely supports its presence in those regions, forming monospecific forests or, more likely, within the typical deciduous forest that covered the northern Iberian Peninsula during the Middle Holocene.

It is important to clarify the reasons for this massive use of yew in archaeological sites dated in the early Neolithic. As mentioned above, yew is appreciated for its qualities of strength, flexibility and durability, so it is an excellent raw material for construction, the manufacture of tools and, of course, for fuel. We should not exclude its use for food, at least for animal fodder. While toxicity is known and seems to be lethal in horses, ruminants tolerate it much better, and evidence exists of yew plantations to feed livestock in northern Iberia in recent times (ABELLA, 2009).

However, if yew is documented in significant values at archaeological sites from $c a .8000 \mathrm{cal}$ $\mathrm{BP}$, it is from $c a .6000 \mathrm{cal} \mathrm{BP}$ when the first relatively significant pollen remains are recorded. In particular, in some natural deposits, peat bogs located in the Eastern Cantabrian Range (Los Tor- nos and Zalama) and the Pre-Pyrenean region (Atxuri and Belate) (Figure 3). They all have continuous pollen values in a quite similar chronology, between $c a .6000-2700 \mathrm{cal} \mathrm{BP}$. These values are generally low, rarely higher than $1-2 \%$, because of yew's pollination characteristics. Although it is an anemophilous tree, its pollen production and dispersal rate is very low. Some studies show a scarce representation in surface samples taken near the tree, and this decreases further with increasing distance from the Taxus stand (HEIM, 1970; NNORYSKIEWICZ, 2003). These factors indicate that even very low pollen values (1-2\%) must attest the local presence of yews. However, peat bogs such Atxuri and Belate, between $c a$. 5500-4750 cal BP, manifest higher percentages $(>2 \%)$. In another peat bog, Saldropo, no continuous values are recorded, only isolated occurrences between $\mathrm{ca}$. 5000-2750 cal BP (Figure 3). In all cases, the evidence of yews is linked to the presence of major deciduous forests in the environment.

In sum, the palaeobotanical data indicate some expansion of yew populations during the Middle Holocene. From ca. 8000 cal BP it seems to be increasingly important, according to anthracological data. But the absence of other palaeobotanical references in this chronology makes it difficult to calibrate its landscape status more accurately. Therefore, we cannot know if this significant use of yew wood reflects the expansion of its populations, or, more probably, the human selection of a raw material that, as it was present in the nearby environment, was highly appreciated because of its excellent conditions for manufacturing tools, weapons and obviously as fuel. The expansion of yew seems definitely proved from $c a .6000 \mathrm{cal}$ $\mathrm{BP}$, when the palynological data show low but significant pollen values, reflecting its increasing importance in the landscape (Figure 3). At this time, anthracological records from archaeological sites also reflect a significant use of yew wood.

The reasons for this expansion of yew populations in the Middle Holocene are probably climatic. After the end of the Late Glacial, with cold conditions and probably seasonal droughts, the Holocene is characterized by more humid and temperate conditions (AMMAN \& al., 2000; Ro- 
BERTS \& al., 2004; RASMUSSEN \& al., 2006). This favoured progressive forest expansion, especially deciduous forests, in northern Iberia and in the Basque Mountains, where the dominant landscape consisted of mesophilous forests, in which hazel, oaks, birch, walnut, lime and elm reached a remarkable importance. In this context of great climatic humidity and mild temperatures, yews found the best conditions for their development.

\section{The TAXUS DECLINE}

If during the Middle Holocene the yew experienced a period of expansion, during the Late Holocene it suffered a significant regression in the Basque Mountains. In the fossil record this can be seen by its progressive decline, although it continues to be present in the charcoal and pollen records (Figure 3).

In the archaeological sequences mentioned above, the use of yew wood decreases significantly, as at El Mirón, where although it never disappears, from $c a$. 4150-3920 cal BP it shows very low values $(<10 \%)$. In other cases such as Aizpea, after the expansion discussed above, it suffers a major regression, although this archaeological level is not dated. Finally, anthracological records from the Sierra de Cantabria show a clear regression in the use of yew between $c a$. 40003000 cal BP, in deposits like Peña Larga, Peña Parda, Los Husos I, Los Husos II and San Cristóbal (Figure 3).

Regarding palynological sequences, there is a decrease, even disappearance, of yew pollen (Figure 3). In the peat bogs of Los Tornos and Zalama continuous values had been recorded in previous chronologies, but from $\mathrm{ca} .3000 \mathrm{cal} \mathrm{BP}$ the pollen diagram shows only sporadic occurrences. The same trend is observed in Atxuri and Belate peat bog pollen records, although in this latter case the presence of yew is documented until the $3^{\text {rd }}$ millennium cal BP. In Saldropo peat bog, although there was never a significant presence, yew disappears from the pollen diagram after $c a$. 2750 cal BP.

Therefore, the available palaeobotanical record indicates a general decline in fossil evidences from $c a .3000$ cal BP, showing a notable retreat of the yew population in the Basque Mountains. It seems that this decline is not due to a single factor, but to a confluence of different elements, which favoured this regressive dynamic in the Late Holocene. Among the major causes, several biological, environmental and anthropic factors can be noted. For instance:

1) Climatic warming during the Late Holocene. Several palaeoenvironmental records indicate a transition to drier conditions during the Late Holocene in Southern Europe (MARTíNEZ-CORTIZAS \& al., 1999; DAVIS \& al., 2003; MAGNY, 1993, 2004; GONZÁLEZ-SAMPÉRIZ \& al., 2008). This was gradual and not abrupt, finally determining lower water availability that could complicate an adequate regeneration of yew, which needs high humidity.

2) Increasing anthropic pressure. Human impact on the vegetal landscape, related to the new economic basis established from the Early Neolithic, is another important cause to consider (MUCINA, 2010). The intense exploitation of the yew, documented since at least $c a .8000$ cal BP (as seen at archaeological sites in the Pre-Pyrenees and southern Basque Mountains) could significantly reduce yew populations. As mentioned, yew wood is extraordinary good for fuel and for the manufacturing of tools. Besides its use as a raw material, some authors (ABELLA, 2009; SCHWENDTNER, 2010) point out another factor: the use of branches for animal folder. Some animal species (horses) do not tolerate its use, due to taxine (a toxic secondary metabolite), but other ruminants (sheep, goats) and wild animals (deer, and roe deer) can browse the yew, consuming green shoots, which could finally lead to the death of the plant.

3) Exclusive competition with other tree species. Yew ecological requirements are very similar to those of the beech, so they may share ecological niches (ABELLA, 2009). The rapid expansion of beech forest in the Late Holocene could have had a negative effect on yews. While beech is a relatively fast growing tree, yew grows very slowly, so it takes a long time (50-70 years) to reach maturity and the first flowering period (Thomas, 2010). Thus, yews may not have resisted this specific competition and found themsel- 
ves restricted to the places in which beech could not thrive, like on rocky limestone slopes. This displacement effect of beech did not affect only yews, but also impacted on other taxa like oak, hazel and birch. However, due to the above mentioned regeneration difficulties; yew was possibly affected the most severely.

4) Self regeneration problems. In a natural and balanced system, yews display several self-regeneration factors that compromise the reproduction of natural specimens (IsZKULO, 2010). Although it is an anemophilous tree, its pollen production and dispersal rate is not very high, resulting in low efficiency of wind pollination and a consequent reduced seed production (ALLISON, 1990). It is a dioecious species which possesses different male and female trees (SCHWENDTNER, 2010). Only the female trees produce flowers and fruits, but trees of both sexes are needed to maintain adequate regeneration. This can be a problem in small populations (ABELLA, 2009). Once seeds are mature, they are generally dispersed by birds and small mammals, but in many cases seeds are eaten by small rodents, reducing the amount of seeds available for germination (GARCÍA, 2007). When this happens, when seeds germinate, small seedlings can be trampled or grazed by livestock or wild animals. All these elements hinder the self-regeneration of the yew.

Because of the combination of these factors, from the Late Holocene onwards, yew was restricted to marginal places in the beech domain and other deciduous forests. It is interesting to note the increasing number of palaeobotanical remains recorded on the coast and in inland valleys (Figure 3) in the late Holocene. Although in all cases they are scattered appearances of pollen and charcoal remains, it may reflect the presence of isolated yew stands at low altitudes $(<500 \mathrm{~m}$. asl), both in interior valleys (archaeological sites of Buruntza and Mulixko Gaina) and on the coast (marshes of Inurritza and Playaundi). Quite different is the case of the archaeological sites of Argarbi Ib and Arrubi, located in the Aralar Mountains at higher altitudes $(819$ and $1260 \mathrm{~m}$ respectively), where at present one of the few well preserved yew forests is located (SCHWENDTNER \& al., 2007).

\section{CONCLUSIONS}

Palaeobotanical records are a very useful tool to explain the behaviour of both major landscape units and individual species displaying a particular evolution over the last millennia; in this case, an overview of the Holocene evolution of yew in the north of the Iberian Peninsula.

Palaeobotanical data show that, yew has been present in several places in the Basque Mountains since at least the Pleistocene. However, during the Middle Holocene a mayor expansion is documented, when it occupied places where it had previously been absent. From $c a .8000$ cal BP a significant use of yew wood can be seen in archaeological contexts. Whether this extensive use responds to a relevant presence in the landscape or the wood was selected by human groups is an issue we cannot solve yet, due to the scarcity of other palaeobotanical records. What is clearly documented is that from ca. 6000 cal BP yew manifests a clear expansion, significantly increasing its presence in the pollen records. This expansion can be related to the optimal development of deciduous forest in the north of the Iberian Peninsula, due to warm and humid climatic conditions.

This phase lasted several millennia, until the Late Holocene, when yew populations suffered a regression. Around ca. $3000 \mathrm{cal} \mathrm{BP}$ we can see both a reduced presence of Taxus in the landscape and also a decrease in its use in archaeological contexts. Since then, it has been restricted to areas of lesser economic use, together with other deciduous elements. This retreat of yews could be due to a combination of biological, environmental and human factors: unfavourable climatic conditions (because of a decrease in water availability) and human overexploitation since Neolithic times, together with competition from other tree species, especially beech, and relatively delicate self-reproduction.

\section{ACKNOWLEDGEMENTS}

S. Pérez-Díaz is currently supported by a post-doctoral research grant (Basque Government) at Toulouse-Le Mirail University. This study was funded by the Consolider Research Program in Technologies for Evaluation and Preservation of Cultural Heritage-TCP-CSD2007-00058 and the 
HAR2011-23716 project (Plan Nacional I+D+i, Spain). S. Pérez-Díaz and L. Zapata are part of the Research Group in
Prehistory IT622-13 / UFI 11-09 at the University of the Basque Country (UPV/EHU).

\section{REFERENCES}

Abella, I. - 2009 - La cultura del tejo - Urueña, Madrid.

Alday, A. -2002- Los últimos cazadores-recolectores de la Iberia interior: La Alta-Media Cuenca del Ebro y la Meseta Norte - Munibe 54: 79-101.

Alday, A., Soto, A., López de Heredia, J. \& Perales, U. 2012 - El abrigo de Martinarri (Obécuri, Treviño): una ocupación del Tardiglaciar en la Cuenca del Ebro Trab. Prehistoria 69 (2): 257-272.

Allison, T.D. - 1990 - Pollen production and plant density affect pollination and seed production in Taxus canadiensis - Ecology 7 (2): 516-522.

ANTHOS -2013 - Sistema de información de las plantas de España - Real Jard. Bot. CSIC \& Fundación Biodiversidad, Madrid. (www.anthos.es).

Ammann, B., Birks, H.J.B., Brooks, S.J., Eicher, U., von Grafenstein, U., Hofmann, W., Lemdahl, G., Schwander, J., Tobolski, K. \& Wick, L. - 2000- Quantification of biotic responses to rapad climatic changes around the Younger Dryas, a synthesis - Palaeogeogr. Palaeocl. 159: 191-201.

Aseginolaza, C., Gómez, D., Lizaur, X., Monserrat, G., Morante, G., Salaverría, M.R. \& Uribe-Etxebarria, P.M. 1996 - Vegetación de la Comunidad Autónoma del País Vasco - Gobierno Vasco-Eusko Jaurlaritza. VitoriaGasteiz.

Beug, H.J. -2004 - Leitfaden der Pollenbestimmung für Mitteleuropa und angrenzende Gebiete - Pfeil. München.

Bosch, A., Chinchilla, J. \& Tarrús, J. -2006- Els objectes de fusta del poblat neolític de La Draga. Excavacions 1995-2005 - CASC Museu d'Arqueologia de Catalunya, Girona.

Bosch, A., Buxó, R., Chinchilla, J., Palomo, A., Piqué, R., Saña, M., Tarrús, J., Terra - 2011- El jaciment neolític lacustre de la Draga - Quaderns de Banyoles, 13, Ed. Ajuntament de Banyoles, Banyoles.

Chabal, L. - 1997 - Forêts et sociétés en Languedoc (Néolithique final, Antiquité tardive). L'anthracologie, méthode et paléoécologie - Éd. Maison Sci. l'Hom. CNRS, París.

Clark, J.D.G. \& Godwin, H. - 1962- Prehistoric ancestors of the weapons which brought England victory at Crecy, Poitiers \& Agincourt: Neolithic Long-bows of 4500 years ago found in the Somersetshire peat - The Illustrated London News. London.

Cope, E.A. - 1998 - Taxaceae: the genera and cultivated species - Bot. Rev. 64: 291-322.

Cortés, S., Vasco, F. \& Blanco, E. - 2000- El libro del tejo (Taxus baccata L.) Un proyecto para su conservación ARBA. Madrid.
Costa-Tenorio, M., Morla Juaristi, C \& Sainz Ollero, H (Eds.) -2005- Los bosques ibéricos. Una interpretación geobotánica - Planeta, Barcelona.

Davis, B.S.A., Brewer, S., Stevenson, A.C., Guiot, J. \& Data Contributors. - 2003 - The temperature of Europe during the Holocene reconstructed from pollen data Quat. Sci. Rev. 22: 1701-1716.

Deforce, K., Bastiaens, J. -2003 - The Holocene history of Taxus baccata (Yew) in Belgium and neighbouring regions - Belg. J. Bot 144: 222-237.

García, D. -2007 - Regeneración natural y conservación del tejo (Taxus baccata L.) en la Cordillera Cantábrica: la importancia de las interacciones ecológicas - In Sierra, L. (Ed.). El tejo en el mediterráneo occidental. Jornadas Internacionales sobre el tejo y las tejeras en el Mediterráneo Occidental. Pp. 31-39, Gen. Valenciana. Alcoy.

Gil García, M.J., Las Heras, R.T. \& Ruiz Zapata, B. 1995 - Degradación antropogénica de la vegetación, en base al análisis polínico, en la Sierra de Guadarrama: Altos de Hontanar (Madrid) - Lazaroa 15: 151-163.

Gonzalez, M.J., Alonso, M.L., Fuentes, C., Sola, A., Gómez, J. \& Cid, J. F. -1998- Álava, Geografiía física y humana de Euskal Herria - Nosotros Los Vascos, Amalur, Vol II: Alava, Lapurdi, Benabarra. Pp. 16-19. Lur. Bilbao.

González-Sampériz, P., Valero-Garcés, B.L, Moreno, A., Morellón, M., Navas, A., Machín, J. \& Delgado-Huertas. -2008 - Vegetation changes and hydrological fluctuations in the Central Ebro Basin (NE Spain) since the late Glacial period: Saline lake records - Palaeogeogr. Palaeocl. 259: 157-181.

Havinga, A. - 1964 - Investigations into the differential corrosion susceptability of pollen and spores - Pollen Spores 6: 621-635.

Havinga, A. - 1967- Palynology and pollen preservation - Rev. Palaeobot. Palynol. 2: 81-98.

Heim, J. -1970 - Les relations entre les spectres polliniques récents et la végétation actuelle en Europe occidentale - Thèse (ined.). Unive. Louvain, Louvain.

Iriarte, M.J. - 1997-. El entorno arqueobotánico del abrigo de Peña Larga. Análisis palinológico - In: Fernandez Eraso, J. (Ed.). Excavaciones en el abrigo de Peña Larga, Ser. Mem. Yac. Alaveses 4. Pp. 137-146. Dip. Foral Álava, Vitoria-Gasteiz.

Iriarte, M.J. -2001 - El entorno vegetal de los pobladores prehistóricos de Aizpea: Análisis polínico - In: Barandiarán Maestu, I. \& Cava, A. (Eds.). Cazadores-recolectores en el pirineo navarro. El sitio de Aizpea entre 8000 y 6000 años antes de ahora. Pp. 315-324. Ser. Anejos de Veleia, Serie Maior, 10. Univ. País Vasco, Vitoria-Gasteiz. 
Iriarte, M.J. - 2006 - El entorno vegetal del abrigo de Mendandia y su depósito arqueológico: Análisis palinológico - In: Alday A. (Dir.). El legado arqueologico de Mendandia. Los modos de vida de los últimos cazadores en la Prehistoria de Treviño. Pp. 405-418. Junta de Castilla y León, Burgos.

Isturiz, M.J. - 1997 - Análisis palinológico del yacimiento arqueológico de Kukuma (Araia, Alava) - In: Baldeon, A. \& Berganza, E. (Coord.). El yacimiento epipaleolítico de Kukuma. Un asentamiento de cazadores-recolectores en la llanada Alavesa (Araia, Alava). Pp. 71-73. Serie Memorias de Yacimientos Alaveses, 3. Dip. Foral Álava, Vitoria-Gasteiz.

Isturiz, M.J. \& Sanchez-Goñi, M.F. - 1990 - Investigaciones palinológicas en la Prehistoria vasca - Munibe (Antropol. Ark.) 42: 277-285.

Iszculo, G. - 2010 - Succes and failure of endangered trees species: low temperatures and low light availability affect survival and growth of European yew (Taxus baccata L.) seedlings - Pol. J. Ecol. 58 (2): 259-271.

Magny, M. - 1993 - Solar influence on Holocene climatic changes illustrated by correlations between past lakelevel fluctuations and the atmospheric $14 \mathrm{C}$ recordQuat. Res. 40: 1-9.

Magny, M. - 2004- Holocene climate variability as reflected by mid-European lake-level fluctuations and its probable impact on prehistoric human settlements Quat. Int. 113: 65-79.

Martínez Cortizas, A., Pontevedra Pombal, X., García Rodeja, E., Novóa Muñoz, J.C. \& Shotyk, W. - 1999- Mercury in a Spanish peat bog: archive of climate change and atmospheric metal deposition - Science 284: 939-942.

Mercuri, A.M., Bandini-Mazzanti, M., Torri, P., Vigliotti, L., Bosi, G., Florenzano, A., Olmi L. \& Massamba, N. I. - 2012 - A marine/terrestrial integration for mid-late Holocene vegetation history and the development of the cultural landscape in the Po Valley as a result of human impact and climate change- Veg. Hist. Archaeobot. 21 (4-5): 353-372.

Moore, P.D., Webb, J.A. \& Collinson, M.E. - 1991 - Pollen Analysis - Blackwell Sci. Publ., London.

Mucina, L. - 2010 - Floristic-phytosociological approach, potential natural vegetation, and survival of prejudice Lazaroa 31: 173-182.

Mujika-Alustiza, J.A., Agirre-García, J., Edeso-Fito, J.M., Lopetegi-Galarraga, A., Pérez-Díaz, S., Ruiz-Alonso, M., Tarriño-Vinagre, A., Yusta-Arnal, I. - In press - La continuidad de la actividad pastoril durante la época romana en la zona de Argarbi (Sierra de Aralar) - Kobie.

Noryskiewicz,A.M. - 2003- Modern pollen deposition in the Taxus reserve in the Wierzchlas (north ern Poland) - 16th INQUA Congr., Reno.

Oakley, K.P., Andrews, P., Keeley, L.H. \& Clark, J.D. - 1977— A reappraisal of the Clacton Spearpoint - Proc. Preh. Soc. 43: $13-30$.

Olaetxea, C. - 1997- Memoria de las excavaciones arqueológicas en el poblado del monte Buruntza, 1992-
1996 (Andoain, Gipuzkoa) - Munibe (Antropol. Ark.) 49: 11-133.

Palomo, A., Piqué, R., Saña, M., Boshc, A., Tarrús, J., Chinchilla, J. \& Gibaja, J.F. - 2005 - La caza en el yacimiento neolítico de La Draga (Banyoles, Girona) - In: Arias Cabal, P., Ontañón Peredo, R. \& García-Moncó, C. (Eds.). III Congreso del Neolítico en la Península Ibérica. Pp. 135-144. Monogr. Inst. Int. Inv. Prehis. Cantabria, 1. Univ. Cantabria, Santander.

Parmar, V.S., Jha, A., Bisht, K.S., Taneja, P., Singh, S.K., Kumar, A., Poonam, J.R. \& Olsen, C.E. - 1999- Constituents of the yew trees - Phytochemistry 50: 1267-1304.

Peñalba, M.C. -1987- Analisi polinikoaren emaitzak. Mulisko-Gaina (Gipuzkoa) - Munibe (Antropol. Ark.) 39:107-109.

Peñalba, M.C. - 1989- Dynamique de végétation tardiglaciaire et Holocène du centre-nord de 1'Espagne d'après l'analyse pollinique - Mem. Doc. (inéd.). Univ. d'Aix, Marseille

Pérez-Díaz, S. - 2012 - El paisaje vegetal durante la Prehistoria Reciente en la vertiente mediterránea de Euskal Herria- Mem. Doc. (inéd.). Univ. País Vasco/ Euskal Herriko Univ., Vitoria-Gasteiz.

Pérez-Díaz, S. \& López-Sáez, J.A. - In press - Prados de Randulanda peat bog (Basque Country, Northern Iberian Peninsula, Spain) - Grana.

Pérez-Diaz, S., Ruiz-Alonso, M., López-Sáez, J.A. \& Zapata, L. - 2010 - Dinámica vegetal en la Sierra de Cantabria (Álava) desde el Neolítico a la Edad del Bronce - Polen 20: 25-40.

Rasmussen, S.O., Andersen, K.K., Svensson, A., Steffensen, J.P., Vinther, B.M., Clausen, H.B., Siggaard-Andersen, M.L., Johnsen, S.J., Larsen, L.B., Dahl-Jensen, D., Bigler, M., Röthlisberger, R., Fisher, H., Goto-Azuma, K., Hansson, M. \& Ruth U. - 2006- A new Greenland ice core chronology for the last glacial termination $-\mathrm{J}$. Geophys. Res. 111: doi: 10.1029/2005JD006079.

Rausing, G. - 1967 - The Bow, some notes on its origin and development - Acta. Arch., Lund, Sweden.

Reimer, P.J., Baillie, M.G.L., Bard, E., Bayliss, A., Beck, J.W., Bertrand, C., Blackwell, P.G., Buck, C.E., Burr, G., Cutler, K.B., Damon, P.E., Edwards, R.,L., Fairbanks, R.G., Friedrich, M., Guilderson, T.P., Hughen, K.A., Kromer, B., McCormac, F.G., Manning, S., Bronk Ramsey, C., Reimer, R.W., Remmele, S., Southon, J.R., Stuiver, M., Talamo, S., Taylor, F.W., van der Plicht, J. \& Weyhenmeyer, C.E. - 2004 - IntCal04 terrestrial radiocarbon age calibration, 0-26 cal kyr BP - Radiocarbon 46: 1029-1058.

Roberts, C.N., Stevenson, T., Davis, B., Cheddadi, R., Brewster, S. \& Rosen A. -2004- Holocene climate, environment and cultural change in the circum-Mediterranean region - In: Battarbee, R.W. et al. (Eds.). Past Climate Variability through Europe and Africa. Pp. 343362. Springer, Dordrecht.

Ruiz-Alonso, M. -2003/2007- Madera carbonizada en los fondos de cabaña de Arrubi y Esnaurreta (Sierra de 
Aralar, Gipuzkoa): vegetación y recursos forestales en la Edad Media - Kobie (Serie Paleoantr.) 27: 131-150.

Ruiz-Alonso, M. \& Zapata, L. -2003 - Análisis antracológico del yacimiento arqueológico de Peña PardaCuad. Arq. Univ. Navarra 11: 217-252.

Sanchez-Goñi, M.F. - 1993- De la taphonomie pollinique à la reconstitution de l'environnement. L'example de la région cantabrique - British Archaeo. Rep. Int. Ser., Oxford.

Sanchez-Goñi. M.F. - 1996- Vegetation and sea level changes during the Holocene in the estuary of the Bidasoa - Quaternaire 7(4): 207-219.

Sánchez-Goñi, M.F. - 2004- La vegetación contemporánea de los grupos Meso-Neolíticos y Neo-Calcolíticos de Kanpanoste (Vírgala, Alava) - In: Cava, A. (Ed.). Kanpanoste (Virgala, Alava), la ocupación prehistórica de Kanpanoste en el contexto de los cazadores-recolectores del Mesolítico, Serie Monografias de Yacimientos Alaveses. Pp. 161-168. Dip. For. Álava, Vitoria-Gasteiz. Schweingruber, F.H. - 1990- Microscopic wood anatomy - WSL/FNP, Birmensdorf.

Schwendtner, O., Miñambres, L \& Cárcamo, S. - 2007 Problemática de conservación de las poblaciones de tejo (Taxus baccata L.) en Navarra. Propuesta de un plan de gestión regional para el tejo - In: Sierra, L. (Ed.). El tejo en el mediterráneo occidental. Jornadas Internacionales sobre el tejo y las tejeras en el Mediterráneo Occidental. Pp. 41-59. Gen. Valenciana, Alcoy.

Schwendtner, O. - 2010 - Supervivencia y crisis del tejo (Taxus baccata L.) en el área cantábrica - In: Sierra, L. (Ed.). II Jornades sobre el teix a la Mediterrànea occidental. Pp. 35-40. Del. Garrotxa. Inst. Cat. d’Hist. Nat. Fund. d’Est. Sup. d'Olot, Olot.

Schwendtner, O. \& Cárcamo, S. - 2001 - Las tejedas de Quinto Real, formaciones forestales relictas - Gorosti 2000/2001: 25-31.

Sierra, L. - 2010 - Distribución del tejo (Taxus baccata L.) en España - In: Sierra, L. (Ed.). II Jornades sobre el teix a la Mediterrànea occidental, Del. Garrotxa. Inst. Cat. d’Hist. Nat. Fund. d’Est. Sup. d’Olot, Olot.

Smart, T.L. \& Hoffman, E.S. - 1988- Environmental Interpretation of Archaeological Charcoal - In: Hastorf, C.A. \& Popper, V.S. (Eds.). Current Paleoethnobotany. Analytical Methods and Cultural Interpretations of Ar- chaeological Plant Remains. Pp. 167-205. Univ. Chicago Press, Chicago \& Londres.

Spindler, K. - 1994 - The Man in the Ice - Crown Trade Paperbacks. New York.

Théry-Parisot, I., Chabal, L., Chrzavzez, J. -2010 - Anthracology and taphonomy, from wood gathering to charcoal analysis. A review of the taphonomic processes modifying charcoal assemblages in archaeological contexts - Palaeogeogr. Palaeocl 291: 142-153.

Thieme, H. \& Veil, S. - 1985- Neue untersuchunen zum eemzeitlichen Elefanten-Jagdplatz Lehringen - Die Kunde 36: 11-58.

Thomas P.A. \& Polwart A. - 2003 - Taxus baccata L. J. Ecol. 91: 489-524.

Thomas, P.A. - 2010 - Response of Taxus baccata to environmental factors - In: II Jornades sobre el teix a la Mediterrànea occidental. Pp. 5-10. Del. Garrotxa. Inst. Cat. d’Hist. Nat. Fund. d’Est. Sup. d’Olot, Olot.

Thompson, G.B. - 1994- Wood charcoals from tropical sites: a contribution to methodology and interpretation - In: Hather, J.G. (Ed.). Tropical Archaeobotany. Applications and new developments. Pp. 9-34. Routledge, Londres.

Varas-Cobo, J. - 2007 - El tejo (Taxus baccata L.) en Cantabria. Necesidad y oportunidad para realizar un plan de gestión de una especie protegida - In: Sierra, L. (Ed.). El tejo en el mediterráneo occidental. Jornadas Internacionales sobre el tejo y las tejeras en el Mediterráneo Occidental. Pp. 77-82. Gen. Valenciana, Alcoy.

Vernet, J.L. - 1991 - Lánthracologie, donnés actuelles, problemas - In: El análisis de los macrorrestos vegetales en la interpretación arqueológica. Madrid.

Zapata, L. -2001 - El uso de los recursos vegetales en Aizpea (Navarra, Pirineo Occidental): la alimentación, el combustible y el bosque - In: Barandiarán Maestu, I. \& Cava, A. (Eds.). Cazadores-recolectores en el Pirineo navarro: el sitio de Aizpea entre 8.000 y 6.000 BP. Pp. 325-359. Anejos de Veleia, serie maior, 10. Univ. País Vasco, Vitoria-Gasteiz.

Zapata, L. -2012 - Holocene wood charcoal from El Mirón cave. Vegetation and wood use - In: Straus, L.G. \& González Morales, M.R. (Eds.). El Miron cave. Cantabrian Spain. The site and its Holocene archaeological record. Pp. 174-196. Univ. New Mexico, Alburquerque. 